\title{
THE ROLE OF FORCE IN STATE FORMATION: A COMPARATIVE ANALYSIS
}

\author{
Emmanuel Ojo, \\ University of Ilorin, Nigeria
}

\begin{abstract}
The basic thrust of this article is an in-depth analysis of the established proposition in the existing literature on civil-military relations (CMR) that the military or instrumentality of force is a sine qua non to the formation and consolidation of the state. From that premise, the article considers the views of the founding fathers of CMR and with historical facts lend credence to that proposition. On the other hand, the article emphasises the fact that force and brute force alone is not sufficient to attain national integration. The study on which this article reports, surveyed stages of state evolution and inferred that force and nation building are in dialectical opposition, whereas consensus and cooperation are required more than force in the process of nationhood. The article infers that in this $21^{\text {st }}$ century, even after attaining nationhood, the state is still in need of very strong armed forces because of the challenges of globalisation, which include terrorism and territorial expansion by neighbouring and far-away states.
\end{abstract}

\section{Introduction}

The chief foundation of all states, whether new, old or mixed are good laws and good arms ... There cannot be good laws where there are no good arms and where there are goods arms there must be good laws. ${ }^{1}$

The above quotation from Niccolò Machiavelli epitomises the thrust of the study reported on here, the aim of which was to explore the nexus between force, state formation and eventual national integration or cohesion. The basic proposition raised by this piece is that all states are founded on force. No doubt, this is a proposition on which both the Conservatives and the Marxists ${ }^{2}$ alike agree. To the

Scientia Militaria, South African Journal of Military Studies, Vol 43, No. 2, 2015, pp. 65-78. doi : $10.5787 / 43-2-1124$
Conservatives, states are founded on force and this is not really a bad development, while Marxists, who subscribe to this perception, to some extent however, also argue that whether old or new states, they are all founded on force 
which is used to oppress the weak, poor and downtrodden in society. The point of divergence to both the Marxists and the Conservatives is not unconnected with the essence of the state.

In The prince, Machiavelli considered the existence of the military which represents force, vis-à-vis the state, when he postulated further, "the best ordinances in the world will be despised and trampled underfoot when they are not supported, as they ought to be, by military power ..."3 Thomas Hobbes too wrote that "covenants without sword are but words". It is imperative to note in the beginning that the kind of military determinism, which this postulation implies, is to be challenged in this article. This is even more so when contemporary reality shows that brute force alone is not all that it takes to consolidate or integrate a polity.

The article is divided into five sections. Following the above introductory remarks, the article proceeds to report on an exploration of the organisational character of the military, vis-à-vis its ability to evolve or enhance nation building, which comprises the second part of the article. The third section dwells on historical excursion on a comparative basis by tracing the evolution of a number of states both developed and developing - emphasising the role of the military. The fourth part expounds state formation with examples from Europe. Part five theoretically displaces the military determinism thesis with the argument that force alone is not only what is needed to attain national cohesion and that in the history of nation states, no state has ever attained national integration by virtue of brute force alone. The article infers that the role of the military is especially required in new states to guarantee statehood while the advanced and developed democracies also require strong militaries to ward off terrorist acts, internal irredentist claims and external aggression that have become one of the features of international relations as a result of globalisation. We now proceed to the organisational characteristics of the military to establish the fact that the highlighted traits of the armed forces are indeed antithetical to nationhood. Much as the armed forces are needed to guarantee state existence, the objective of national integration is beyond its purview.

\section{Organisational character of the military}

The emergence of the centralised nation-state undoubtedly has provided a primary raison d'être for a standing army. A military organisation, like other institutions of the state, is the instrument through which the state furthers its goals and objectives. There are basic features that are peculiar to the military, which distinguish it from all others that are non-military. The military - being a positive instrument and coming into existence by order or decree and with the sole aim of 
fighting to win wars - has certain peculiar organisational characteristics. These features are centralised command, hierarchy, discipline, internal communication and esprit de corps with corresponding isolation and self-sufficiency. ${ }^{5}$ Organisation is central to effective performance of the military function. According to Finer, "marked superiority in organisation, a highly emotionalized symbolic status and a monopoly of arms" are the three advantages which the armed forces have over civilian organisations. ${ }^{6} \mathrm{He}$ asserts further that even where the army is poorly organised or maintained, it is still much more highly structured than any civilian group. This idea of organisation of the military is also emphasised by Janowitz, who describes the nature of military organisation particularly in terms of their skills, structures and career lines, their level of education, their social solidarity or esprit de corps and their professional and political ideologies, such as patriotism and puritanism, ${ }^{7}$ which distinguish the military from their civilian counterpart.

The military is arranged in a pyramid of authority. The hierarchical structure, like the characteristics of centralisation, derives from the military's basic imperatives to fight as a unit. "[A]n army should have but one chief, a greater number is detrimental," argues Adekanye, quoting Machiavelli. ${ }^{8}$ A military must have supreme directing command, hence centralisation. The command must transmit its orders from the highest to lowest ranks, thus, the requirement of hierarchy. Following from centralisation of command in the pyramid structure, obligation to obedience and discipline, the condition of unquestioning obedience is manifested by the depersonalisation of the soldier. The army will act in unity to the word of command, and this requires a unique system of communication. This is because any military organisation depends rather heavily on intelligence, surprise and adequate information for effective operation. So significant is communication to the operations of the military that Adekanye notes, "even the most technologically backward society always found the ways and methods, however primitive and clumsy, of meeting these particular needs of its army". 9 It is through communication networks that the soldier is made aware of its martial purpose and the need for identifying with the groups and maintaining solidarity. The putting together of a set of beliefs, a sense of belonging acquired through socialisation, and training and interaction fosters the spirit of brotherliness among the soldiers. In the words of Adekanye, "the factor of ever-present exposure to danger and death imposes on the military man, in conjunction with his team mates, the compelling necessity of and/or logic of collective actions", ${ }^{10}$ this constitutes their esprit de corps. Modern armies are therefore far more organised and professionally cohesive than any other institution of the state. 
Furthermore, the ability of the military to show a degree of specialised knowledge in the management and organisation of violence, a feeling of social responsibility towards their client - the state - the adherence to certain ethical rules, with a corporate tradition stemming from the common training and collective attachment to certain doctrines and methods makes it a profession. Janowitz and his organisational counterparts, supporting this argument, put it thus:

The unity, technical competence, professional identity and patriotic values of military organisations in new states place them in sharp contrast to the civilian sector which is often badly divided and technologically backward. ${ }^{11}$

In the same vein, Dudley, identifying predisposing factors of the military to coups, notes such superior qualities of the military over the civilians to include variables as:

The structure and composition of the armed forces, taking into account the possibilities for mobility within the military; the commitment to, or degree of professionalism of, armed forces personnel and the prevailing ideology held by, or normative orientation of, the military. ${ }^{12}$

Politically too, moral prestige is an advantage to the military. These virtues are associated with the soldiers' choice of career. These virtues are not always fully respected, but most of the time and in many countries, traits like courage and discipline cum self-sacrifice and patriotism, which are identified with the soldier, make the military admired. ${ }^{13}$ Furthermore, writing on the features of the military, Julius Ihonvbere argues that the army is conceived as an ideal type characterised by certain organisational features. He points to the fact that -

The officers while in training have imbibed certain qualities such as puritanical ethic, professionalism dedication, nationalistic ethos and an in-group cohesion which will make them act in unity and decisively in the execution of military or political functions. The skills acquired in training, coupled with a high sense of national identity, managerial ability, all go to explain the unity, strength and decisiveness of the military in the emerging states and creates a 'competence gap' between the military and other sectors of the society. ${ }^{14}$

In view of the foregoing, military rule is authoritarian perhaps, because of the character of the military whose significant elements are command and 
obedience, supra-individuality and confrontation rather than compromise. It is these elements which constitute the military value system. It is also this "military frame of mind", to use Martin Dent's apt phrase, ${ }^{15}$ which military men bring into politics and which is reflected in their style of governance. In the application of the military frame of mind to government, military leaders conceive of society in roughly the same terms as the regiment where authority is administered from the top downwards. Dent argues in this connection, "the military are accustomed to controlling their lower ranks by a strict chain of command in which obedience and loyalties are the prime value"; ${ }^{16}$ hence, "the idea of leaders taking advice from the led or tailoring their course according to the feelings expressed by the lower ranks is repugnant to the idea of command". ${ }^{17}$ There is an assumed impropriety in listening too closely to the opinions of those at the bottom of the hierarchy. It is in this sense, therefore, that military rule could, with some justification, be said to be dictatorial.

In the same vein, the military, along with the highlighted traits, is antithetical to democracy and neither could be a good instrument for nation building. This will be demonstrated later in this article.

\section{Historical and comparative analysis of force as foundation of states}

The case of non-African states

The primary objective of this section of the article is to present a comparative historical analysis to establish the postulation that supports the basis of force as foundation of states in virtually all regions and climes of the world. No doubt, this generalisation is true of even the United States of America (USA) where SM Lipset ${ }^{18}$ in his book, The first new nation, chronicles the historical metamorphosis of the United States along with the virtue of democratic ethos. He however emphasises the role of democratic values. Perhaps the unintended goal Lipset wants to achieve is to play down the role of force in the foundation of the United States, whereas, in the foundation of the United States, the role of force was very pronounced. For instance, historical facts revealed that Native Americans had to be defeated on their lands to be occupied by new immigrants, while Texas and New Mexico were seized from the Mexican empire. Not only that, the War of Independence was waged in 1776 against colonial Britain. A bitter agonising internecine war was also fought between the North and the South wanting to break away from the United States. All these had to be done for the federation of the United States to be consolidated. Nonetheless, Native Americans still live in a very 
inhospitable part of the country. ${ }^{19}$ The United States claims to be a model of a democratic federal state, but the role of force cannot be obliterated from her history.

Be that as it is, the proposition has always been true of virtually all European countries. When one considers the foundation of Great Britain, of which the foundation dates back to the Norman conquest of 1066, which was soon followed by many wars of succession among English kings, as well as wars of territorial expansion by which England was annexing one dukedom after another, such as Scotland, Wales and Ireland among others. This part of British history, when England was seizing territories that were supposedly independent, cannot be obliterated easily either. Interestingly, Wales still thinks independently of the United Kingdom. ${ }^{20}$

Contemporary Belgium emerged as a result of the revolutionary war of 1448. Germany was united in 1887 - a blood and iron creation of Otto von Bismarck - as a result of force and subtle diplomacy. In the same way, Eastern and Western Germany emerged via military factors, this time, externally imposed. The unification of Germany (East and West) under the Kaiser with the ace diplomat Von Bismarck cannot easily be forgotten in the historical metamorphosis of modern Germany. The conversion of Italy from a mere geographical expression according to Mazzini, into a united country by Bismarck's counterpart - Count Cavour - could not have been possible without the use of force. Cavour believed very strongly in the unification of Italy and he also believed that unification was possible only if Austrian forces were defeated. Therefore, when the opportunity came in 1848 to attack the Austrian forces, Cavour championed the cause of all other Italian states against the Austrians. ${ }^{21}$ Eventually, Sicily, Rome, Naples, amongst others, that were independent entities and principalities, were unified with Italy but using brute force in most cases. The story is indeed similar in virtually all European countries at their formative stages. One cannot easily forget the creation of Soviet Union in 1917 by Stalin, which had disintegrated in the early 1990s.

The case of African states

In the pre-colonial, colonial and post-colonial phases of African states, the influence of force is no doubt preponderant. Long before European penetration of Africa, local tribes and communities engaged themselves and each other in intratribal, inter-tribal and internecine warfare to subjugate both nearby and far-away neighbours. In the process, empires started evolving. Notable among them then were the defunct Abyssinian Empire, which metamorphosed into contemporary Ethiopia. Ethiopia had its state established as a result of one overbearing ethnic group 
imposing its wish on the rest, i.e. the Amharic ethnic group. It is a conquest state in which the dominant Amharic group along with the Coptic Church imposed its will on the rest of society with the instrumentality of force. In the process of consolidating Ethiopia, there were several conflicts with Italy, which was aspiring to colonise the territory. Incidentally, in the whole continent of Africa, Ethiopia was never subjugated, but at a price - force - to ward off external colonisation.

Corroborating the above observation, Mathurin Houngnikpo recalled that a few years before European conquest, Africa suffered from internal aggression. ${ }^{22}$ In East Africa, Ethiopian King Menelik II's army defeated and occupied the Ogaden. ${ }^{23}$ In Southern Africa, Mzilikazi, the chief of the Khumalo, used his powerful army to impose his will on Mashonaland. Shaka's regiments, closely drilled and highly disciplined, frequently harassed the Nguni and the Sotho.

According to Schraeder:

The reign of Shaka is widely renowned for his creation of a militaristic Zulu empire that expanded its authority by conquering neighbouring peoples and absorbing their warriors into the national army. Those warriors refusing to pledge direct allegiance to Shaka were put to death on the battlefield. The national army was designed around a series of military-oriented age-sets, and successfully used military innovations such as assegais (short spears) on the battlefield. A standing national army and a militaristic ethic fostered a sense of unity that was strongly tied to Shaka's personal rule. ${ }^{24}$

In West Africa, offensive wars by the empires and kingdoms of Mali, Songhay, Ashanti, Oyo, Danhome, Benin and others are well documented. ${ }^{25}$ The link between economic and military survival was evident in the Ashanti kingdom where statehood and imperial ambitions reinforced the military factor. Fortes's comment shows the centrality of war in the definition of statehood:

The Ashanti state was created and maintained by war, and a military ideology remained a central feature of its structure to the end. Guns and gold were its training foundations. As imported firearms spread among the populace, the chiefdom which could muster the largest supplies of guns and ammunition had every chance, if ably led, to triumph in the inter-tribal wars. ${ }^{26}$

Among the Akans, command hierarchy was important, and the role of military organisation is reflected in Osuwu's remarks about Agona states: 
The organisation of stools and swords in Agona is nothing but military formation based on the logistic of war developed by the people. Political organisation is ipso facto military organisation. ${ }^{27}$

Like Bunyoro, Buganda and Zulu, the Oyo Empire is a conquest state in which the military played a vital role. The warrior was relentlessly cultivated because the Alafin (king) had to exhibit militarism or lose his throne. According to Uzoigwe:

To ensure that the disaster which occurred in the reign of Onigbogi was not repeated, the Alafins of Oyo began a policy of military reorganization and militant expansion of Oyo influence. Conquered areas were placed under the effective administration of the Ajele (political residents). It was during this period that Alafin Ajagbo created the position of Are Ona Kakanfo (generalissimo of Oyo's army). The Kakanfo (as he was popularly known) was expected to wage war regularly, to win each war 'within three months or be brought home dead'. By mid-eighteenth century, Oyo had become the largest state system in Yorubaland. It had also become a military machine which, if not properly controlled, could prove dangerous for political stability. $^{28}$

From the foregoing, there is no doubt that pre-colonial African states had their foundation in military warfare. The colonial states in Africa further experienced wars with the imperialists. In the whole of Africa as it exists today, there are only two exceptions to the influence of colonial force in their foundation, namely Ethiopia (formerly Abyssinia) and Liberia among all the so-called 'new states' of sub-Saharan Africa. Virtually all other states on the continent owe their origin in part to imperialism, which is above all a military phenomenon. These African states were created by the process in which competing European powers such as Portugal, Spain, Britain, France, Germany and Italy at different times and by different processes and through different mediums and for whatever the reason(s), carried out colonisation of various territories as their possessions by using entrenched military force combined very often with gun-boat diplomacy.

It would be recalled that a number of African countries got their independence through liberation struggles and wars with their colonisers all in an attempt to create their states. Much as Nigeria did not wage a liberation war in the real sense of it, shortly after independence, it was engrossed in a 30-month agonising civil war with Biafra, which intended to secede from the Nigerian federation. The federal arrangement in Nigeria is still evolving and sustained with 
military might. ${ }^{29}$ The story of virtually all other states on the continent is not really different from these militarily sustained systems. Not a single one is exempted from the profound effect of force.

State formation: Examples from Europe

Nevertheless, we can easily make a number of deductions on state formation and disintegration vis-à-vis the role of force. In a perceptive lecture, Bolaji Akinyemi made some critical observations to illustrate, from the emergence of contemporary nation states, how the Soviet Union was formed in 1917, only to disintegrate in 1991, after 74 years. Yugoslavia, formed in 1919, also disintegrated in 1991, after 72 years. A reverse illustration is that of Germany, which was split into two in 1945 only to be united again in 1992. In other words, an artificial separation of 47 years was not sufficient to break the mythical identity of the German nation. ${ }^{30}$ Obviously within this context, we must distinguish two categories of bringing a state of many nationalities into being, which could be voluntary or involuntary. The voluntary mode involves a willing amalgamation of different nationalities into one state, i.e. a voluntary surrender of sovereignty. Two classical cases of this mode of voluntary surrender of sovereignty are the processes which brought the United States and Australia into being. Even with the voluntary surrender, the system may still have to be reinforced by military strength because of internal irredentist claims later. For the purists, one can immediately concede that the original divisions within the United States and Australia were not primarily along nationality lines. The process started with the establishment of different colonies within each territory and ended with the voluntary amalgamation of the territories. The second involves forceful amalgamation, using military might without consultation with those involved. If we were to go back into distant history, say as far back as 2000 years ago, practically all the states in the world were formed this way. Years back, each of the present states in Asia, Europe, the Americas and even Africa did not have the present national configuration that it has now. For instance, we tend to think of the British nation - and I am not referring to the United Kingdom - as a monolithic whole that has been there since creation. In fact, as late as the $7^{\text {th }}$ century, England was made up of the independent states of Cornwall, Kent, Wessex, Sussex, Mercia, Northumbria and East Anglia. By AD 878, the area had undergone forceful amalgamations and split-ups to produce new states such as Wessex, Bernicia and Danelaw, among others. ${ }^{31}$

Nonetheless, we do not need to go as far back as 2000 years. In the last 85 years, the map of Europe has been drawn and re-drawn several times. The first major re-drawing was in 1918 after the First World War, which involved forceful 
mergers and forceful dissolution of about 15 states. It was followed in 1945 by another re-drawing of the map, which again led to the disappearance of some states. It was then followed in 1991 by another re-drawing of the map, which led to the disappearance of the Soviet Union and Eastern Germany and the re-emergence of Russia, Ukraine, Moldova, Armenia, Azerbaijan, Turkmenistan, Kazakhstan, Belarus, Estonia, Lithuania, Latvia, Georgia and another half a dozen states. We have also witnessed the disappearance of Czechoslovakia and the emergence of Czech and Slovakia. In the past few years, we have witnessed the completion of the total disappearance of the Federation of Yugoslavia which started in 1991 and which has led to the emergence of Slovenia, Macedonia, Bosnia, Kosovo and Croatia. In other words, within 75 years, Europe has witnessed not one but several massive nationality revolutions, which Africa has not experienced since the Treaty of Berlin in $1884 .{ }^{32}$ In all these, the pervasive role of the military/force is noticeable. This has given credence to the postulation that force makes nations. No doubt, even if the role of the military is minimal or passive, it must have been the result of the military hierarchy being in support of the civil movement for the redrawing of maps.

\section{Varying role(s) of force at stages of political evolution of multi-ethnic states}

From the foregoing, one may perhaps be tempted to over-generalise the proposition that in the early stages of state formation, 'war makes nations'. Thus, there is a need to introduce some modifications and qualifications vis-à-vis the role of force in the evolution of nation states, most especially the multi-ethnic ones that are plural or deeply divided societies. In this section of the article, we do not imply a thesis of military determinism, nor are we suggesting that the state is the same thing as a nation in that its military factors are essential to the formation of the former. Force must not be all that is required to build the latter. We do not say that the military factor is the most imperative alone to secure the building of a nation state, what we are saying is that other variables such as consensus building and persuasion, among others, are equally expedient.

In a discerning piece, Fred Onyeoziri identifies a number of ways by which the cooperation of citizens could be gained without necessarily relying on force alone. The first one he notes is the use of force and state coercion to compel cooperation. This is in line with the argument of this article from the beginning. The second one is through ideological persuasion, in other words, influencing the political ideas of the people and moulding their political reality as part of the attempt to persuade them that the government serves their interest and therefore deserves their support. The third strategy is consensus building to secure the cooperation of 
the citizenry. This strategy is usually the most convenient and stable basis for keeping the loyalty of the citizens. ${ }^{33}$ In essence, there is a small role for force after the stage of state formation as depicted in Table 1 below.

\begin{tabular}{|c|c|c|}
\hline No. & Stages of evolution of states & Varying role(s) of force \\
\hline 1. & $\begin{array}{c}\text { State formation, consolidation and } \\
\text { maintenance }\end{array}$ & Maximum \\
\hline 2. & $\begin{array}{c}\text { Creating political order, institutions and } \\
\text { political leadership }\end{array}$ & Average \\
\hline 3. & $\begin{array}{c}\text { Nation building, national integration and } \\
\text { creating a community }\end{array}$ & Minimal \\
\hline
\end{tabular}

Table 1: Varying role(s) of force at stages of political evolution of states

From the above table, it is obvious that it was the stage of state formation, consolidation and maintenance that required maximum use of force. The reason is not far-fetched. State creation is the initial act of physically endowing a given territory with legal sovereignty and territorial integrity. This is done via a number of methods. First, it may be through colonialism, which is never without the preponderance of force, or it may be through annexation of a territory. If not for the timely intervention of the United Nations, the late Saddam Hussein of Iraq would have annexed Kuwait. Peking (now called Beijing) in old China was a territory forcefully annexed by China. Perhaps a very rare instance is voluntary cooperation by independent territories to form a new state.

The second stage in the table above is that of creating political order, institutions or political leadership among others. This stage refers to the process of instituting a government and political order that enjoy sufficient legitimacy and authority. At that stage, the average role of the military may be required.

The third stage is that of nation building or community making, which refers to the process of infusing the peoples of a given territory, who otherwise differ as regards custom, religion and sometimes language, with a sense of common belonging and shared identity or in short, what could be called "national integration'. ${ }^{34}$ It is however imperative to note that nation building is a slow, neverending process, and no society ever achieves the goal as a result of centrifugal and centripetal forces in virtually all nation states. Unlike the act of state creation, which is more or less the physical act involving imposition of human will, nation building involves the psychosocial reconstruction of individuals, endowing them with a common identity by the very logic of the situation. State creation is a more easily attainable goal than nation building. It is therefore not surprising that even in the 
more established states that have long achieved political consolidation, nation building still remains an unfinished task.

\section{Conclusion}

Finally, what we have done here was to consider briefly the position of the founding fathers of CMR alongside the argument that force is perhaps what is required to build a nation. Much as the role of force and military factors cannot be over-emphasised in terms of the foundation of states, we have equally argued that force alone cannot be the determining factor as states gradually move away from the foundation stage.

To secure the cooperation of the citizenry, consensus building for peaceful co-existence supersedes military might. With the new wind of democracy blowing all over the world, the military and democracy are in dialectical opposition. The military is a taut chain of command; democracy is a benign anarchy of diversity. Democracy presupposes human sociability; the military presupposes its total absence, the inhuman extremity of killing the opposition. ${ }^{35}$ In that wise, democracy and force are antithetical. However, when one takes away force, most states today will disintegrate upon the problematic nature of achieving national integration.

\section{Endnotes}

1 Machiavelli, N. The art of war (Wood, N, ed) (from the Ellis Farneworth translation). New York: Bobbs-Merril, originally published in 1532.

${ }^{2}$ Conservatism, less an ideology, many conservatives would say, than a cast of mind. Conservatives reject social engineering for its own sake: they accept that people are imperfect, different and unequal. The wisdom of the past is secreted in society's traditions and institutions; these should be respected. Change is therefore justified only where it is clearly necessary... On the other hand, Marxian theory of state is nothing but a corollary of Marxian Interpretations of History. According to the classical view the state exists for the common good. According to the Communist Manifesto, it is the executive committee of the bourgeoisie. According to Engels, it is nothing more than a machine for the oppression of the class by another. For the views of both see, Chaturvedi, AK. Dictionary of Political Science. EPP Books Series. Benin: Nigeria Limited, 2006, 66 \& 189.

${ }^{3}$ Machiavelli op. cit.

4 Cited in Adekanye, B. "Machiavelli and the military: The Prince and the psychology of empty power". Paper presented to and used as a background 
paper by the Defence and Security Group of the National Workshop in Planning Strategy for the 1980s. Nigerian Institute of Social and Economic Research (NISER) and Federal Ministry of Economic Development, University of Ibadan, Ibadan, 9-15 January 1978.

5 Finer, SE. The man on horseback: The role of the military in politics. Harmondsworth: Penguin, 1962.

${ }^{6}$ Ibid.

${ }^{7}$ Morris, J. The military in the political development of new nations: An essay in comparative analysis. Chicago, IL: University of Chicago Press, 1964.

8 Bayo, AJ. "Military organisation and federal society". Quarterly Journal of Administration 16/1 \&2. 1981/1982. 10.

${ }^{9}$ Ibid., p. 13.

${ }^{10}$ Ibid., p. 14.

${ }^{11}$ Janowitz op. cit.

12 Dudley, BJ. Introduction to Nigerian government and politics. Ibadan: Macmillan Press, 1982. See also Huntington, S. Political order in changing societies. New Haven, CT: Yale University Press, 1962.

${ }^{13}$ Ihonvbere, OJ. "Instability and military intervention in politics in the periphery". In Sanda, AO, Ojo, O \& Ayeni, V (eds), The impact of military rule on Nigeria's administration, Ife: University of Ife Press, 1987, 124-140.

14 Dent, M. "Military leadership in Nigeria". Unpublished seminar paper, Manchester, April 1968, 9, also quoted in Sambo, A. "Transition to democracy in Nigeria: Possibilities and limitations". In Omoruyi, O (ed), Democratization in Africa: Nigerian perspective Vol. 1, Benin City: Hime and Hima, 1994, 21.

15 Dent, M. "The military and the politicians". In Panter-Brick, K (ed), Nigerian politics and military rule: Prelude to the Civil War, Oxford: Athlone Press, 1990, 19.

${ }^{16}$ Ibid.

17 Ibid.

18 Cited in Ojo, EO. "Military foundation of states". Unpublished monograph.

Kwara State: Department of Political Science, University of Ilorin, n.d.

19 Ibid.

${ }^{20}$ Fisher, HAL. A history of Europe: From the beginning of the $18^{\text {th }}$ century to 1935. London: Fontana/Collins, 1976.

${ }^{21}$ Omolewa, M. History of Europe (1789-1919). Ibadan: Aromolaran, 1978, 46-47.

${ }^{22}$ See Ojo, EO. Mechanisms of national integration in a multi-ethnic federal state:

The Nigerian experience. Ibadan: John Archers, 2009. 
23 See Akinyemi, B. "Nigeria, a mere geographical express". Lecture in commemoration of June 12 and the $25^{\text {th }}$ anniversary of the creation of Ondo State, Akure, 20 June 2001, 30.

${ }^{24}$ Ibid.

25 Ibid.

${ }^{26}$ See Onyeoziri, F. "The mass media as political resource". Paper presented at a seminar on The Mass Media and Society, Ibadan, 1982, also cited in Ojo, EO. "The mass media and the challenges of sustainable democratic values in Nigeria: Possibilities and limitations". Media, Culture and Society 25/6. 2003.829.

${ }^{27}$ See Ojo, Mechanisms of national integration, op. cit., pp. 15-19.

${ }^{28}$ Ibid.

29 Ibid.

${ }^{30}$ Akinyemi op. cit., p. 30.

31 Ibid.

32 Ibid.

${ }^{33}$ See Onyeoziri op. cit.

${ }^{34}$ Ojo, Mechanisms of national integration, op. cit.

35 Ake, C. “A plausible transition”. Tell 39. 25 September 1995. 